Journal of Indonesian Tourism, Hospitality and Recreation --- Volume 2, No. 2, October 2019

eISSN: 2654-4687 ----- pISSN: 2654-3893

\title{
PERBEDAAN CUSTOMER SERVICE EXPERIENCE PADA GENERASI Y DAN GENERASI Z DALAM MELAKUKAN PEMESANAN ONLINE FOOD DELIVERY MELALUI APLIKASI GO-FOOD
}

\author{
Viany Revita Wijaya ${ }^{(1)}$, Grace Irene Warouw ${ }^{(2)}$, Sienny Thio $^{(3)}$ \\ (1)(2)(3) Program Studi Manajemen Perhotelan, Fakultas Bisnis dan Ekonomi, Universitas \\ Kristen Petra, Surabaya \\ vianyrevitaw@gmail.com,grcirene@live.com,sienny@petra.ac.id \\ Submitted: 20 September 2019 Revised:25 September 2019. \\ Accpeted: 1 October 2019
}

\begin{abstract}
ABSTRAK
Penelitian ini bertujuan untuk mengetahui customer service experience dari generasi $\mathrm{Y}$ dan generasi $\mathrm{Z}$ serta melihat apakah terdapat perbedaan pada dua generasi tersebut dalam melakukan pemesanan online food delivery melalui aplikasi GO-FOOD yang dilihat dari faktor psikologis dan faktor fungsional. Penelitian kuantitatif digunakan dalam penelitian ini dengan menyebarkan kuesioner kepada 145 responden generasi Y dan 128 responden generasi Z di Surabaya. Selanjutnya, data diolah dengan menggunakan analisa statistik deskriptif dan independent sample t-test untuk mengetahui apakah terdapat perbedaan signifikan dari dua generasi tersebut dalam melakukan pemesanan makanan secara online. Hasil penelitian menunjukkan bahwa hanya "trust" dan "value for money" yang merupakan sub-variabel dari faktor psikologis yang memiliki perbedaan yang signifikan antara generasi $\mathrm{Y}$ dan $\mathrm{Z}$.
\end{abstract}

Kata Kunci : Customer service experience, generasi Y, generasi Z, online food delivery.

\section{DIFFERENCES IN CUSTOMER SERVICE EXPERIENCE BETWEEN GENERATION Y AND GENERATION Z IN ORDERING FOOD SERVICE DELIVERY USING GO- FOOD APPLICATION}

\begin{abstract}
This research aims to investigate customer service experience of generation $Y$ and generation $Z$ and to examine differences between the two generations in ordering online food delivery using GO-FOOD application from the perspective of psychological dan functionality factor. Quantitative research was employed in this paper by distributing questionnaires to 145 respondents of generation $Y$ and 128 respondents of generation $Z$ in Surabaya. Then, data was processed using descriptive statistics analysis and independent sample t-test in order to investigate whether there is a significance difference between the two generations in ordering online food delivery. The result of this research shows that only "trust" and "value for money" which are sub-variables of psychological factor have significantly difference between generation $Y$ and generation $Z$.
\end{abstract}

Keywords: Customer service experience, online food delivery, Y generation, $Z$ generation

\section{PENDAHULUAN}

Ditinjau dari jumlah populasi penduduk beserta luas wilayahnya, Surabaya menempati peringkat kedua sebagai salah satu kota terbesar di Indonesia setelah Jakarta (Gitasari, 2017). Surabaya dikenal sebagai 
Viany Revita Wijaya, Grace Irene Warouw, Sienny Thio: PERBEDAAN COSTUMER

SERVICE EXPERIENCE PADA GENERASI Y DAN GENERASI Z DALAM

MELAKUKAN PEMESANAN ONLINE FOOD DELIVERY

\section{MELALUI APLIKASI GO-FOOD}

kota maritim yang tidak sekedar menjadi pusat dagang dan budaya, tetapi juga sebagai kota yang kaya akan cita rasa dan aneka makanannya.

Pemerintah telah menetapkan 15 sub sektor dalam ekonomi kreatif di Indonesia antara lain periklanan, mode, kerajinan, film, musik, seni pertunjukkan, radio, dan televisi. Dari 15 sub sektor ekonomi kreatif tersebut, Chandra (2016) menyatakan bahwa terdapat tiga sub sektor ekonomi kreatif yang memberikan memberikan kontribusi dominan terhadap Produk Domestik Bruto (PDB) Indonesia, yaitu kuliner, mode, dan kerajinan. Sub sektor kuliner memberikan kontribusi terbesar diantara dua sektor lainnya, yaitu sebesar 209 triliun rupiah. Dari data tersebut, dapat dikatakan bahwa sektor kuliner Indonesia menjadi salah satu penggerak ekonomi masyarakat (Chandra, 2016).

Perekonomian dan perkembangan bisnis di Indonesia saat ini tengah marak dengan model bisnis sharing economy. Henry BL Toruan yang merupakan ekonom TIS Intelligence mendefinisikan sharing economy sebagai sebuah proses mengoptimalisasi sumber daya melalui sebuah sistem teknologi jika dilihat dari perspektif ekonomi. Sharing economy dapat dimanfaatkan oleh masyarakat Indonesia untuk mengatasi ketidak-efisienan tersebut (Hutabarat, 2018).

Ajrina dan Panji (2016) mengemukakan bahwa salah satu faktor utama yang melatarbelakangi bangkitnya sharing economy serta menjadikan model bisnis ini banyak didukung di Indonesia adalah kemunculan platform marketplace di internet yang dapat menciptakan relasi baru, yaitu konsumen-penyedia layanan online food delivery-pemilik bisnis restoran. Faktor tersebut menjadi pertimbangan banyak perusahaan teknologi di Indonesia untuk mengadopsi sharing economy sebagai model bisnis. Salah satunya adalah bisnis online food delivery milik GO-JEK, yang dikenal dengan GO-FOOD.

GO-FOOD adalah layanan pesan-antar makanan milik perusahaan jasa GO-JEK yang letak perbedaannya terdapat pada objek jasa yang ditawarkan, yakni jasa yang ditawarkan berupa mengantar makanan dan minuman (Wardani, 2018). Suksesnya layanan GO-FOOD dinilai Nadiem yang merupakan CEO GO-JEK dapat turut berkontribusi terhadap pelaku bisnis usaha mikro, kecil, dan menengah (UMKM) di bidang kuliner.

Nadia Tenggara yang merupakan Head Of Business GO-FOOD ingin mengembangkan bisnis yang sudah semakin berkembang pesat ini dengan mencari tahu melalui survei mengenai usia pengguna layanan GO-FOOD guna meningkatkan layanan yang akan diberikan (Josina, 2017). Hasilnya menyatakan bahwa $60 \%$ pengguna layanan GO-FOOD di seluruh Indonesia merupakan anak-anak muda, sebesar 35\% berada di rentang usia 18-25 tahun dan 25\% berada di rentang usia 26-35 tahun. Menurut Miller dan Associates (2011), usia ini termasuk ke dalam generasi $\mathrm{Y}$ yang dikenal pula sebagai generasi Milenial karena generasi tersebut lahir antara tahun 1980 dan 2000. Solomon (2014) juga memaparkan bahwa generasi Y merupakan generasi terbesar sepanjang sejarah dan juga generasi yang nyaman dengan teknologi dan tidak dapat hidup terlepas dari internet. Hingga saat ini belum banyak peneliti yang membahas tentang customer service experience pada generasi $\mathrm{Y}$ dan $\mathrm{Z}$ dalam melakukan pemesanan online food delivery khususnya melalui aplikasi GO-FOOD dimana dua generasi ini sering kali menggunakan jasa layanan GO-FOOD untuk melakukan pemesanan makanan dan minuman. Oleh karena itu, penulis tertarik untuk melihat customer service experience pada generasi $\mathrm{Y}$ dan generasi $\mathrm{Z}$.

\section{LANDASAN TEORI \\ Pengalaman Konsumen}

Pengalaman konsumen dapat didefinisikan sebagai suatu respon kognitif yang berhubungan dengan emosi, perilaku, sensorik, dan sosial konsumen terhadap produk/layanan yang ditawarkan oleh 
perusahaan selama proses pembelian atau penggunaan produk/layanan tersebut (Lemon Verhoef, 2016). Hal serupa disampaikan oleh Meyer dan Schwager (2007), respon yang berasal dari dalam diri konsumen dan sifatnya subjektif terhadap kontak secara langsung maupun tidak langsung dengan perusahaan produk/layanan merupakan definisi dari pengalaman konsumen.

\section{Online Customer Service Experience}

Menurut Trevinal dan Stenger (2014), online customer experience merupakan pengalaman yang bersifat komprehensif dan subjektif yang timbul dari interaksi antara lingkungan berbelanja, konsumen, dan aktivitas berbelanja itu sendiri. Konsumen dalam konteks online tidak dapat dianggap sebagai pembeli saja, tetapi juga sebagai pencari informasi dan pengguna teknologi (Cho \&amp; Park, 2001).

Klaus (2013) dalam penelitiannya mengategorikan dimensi customer service experience menjadi dua dimensi utama, yaitu:

\section{Faktor Psikologis}

Merupakan faktor yang memegang peranan penting dalam mengatasi kendala yang dialami konsumen ketika menggunakan media online karena tidak ada kehadiran fisik yang berkaitan dengan situs web (Klaus, 2013). Terdapat tiga sub-dimensi yang digunakan untuk mengimplementasikan faktor psikologis, yaitu:

a. Trust

Beberapa faktor yang membuat konsumen enggan untuk menggunakan layanan online adalah kurangnya kontak secara perseorangan serta anonimitas dari internet yang membuat konsumen ragu untuk menggunakan situs web.

b. Value for money

Value for money mencerminkan pandangan konsumen mengenai internet sebagai saluran yang menawarkan nilai yang lebih baik dibandingkan dengan toko secara fisik.

\section{c. Context Familiarity}

Context familiarity mengacu pada potensi dalam situs web untuk membuat pengalaman layanan konsumen online dapat serupa dengan konsumen ketika membeli di toko fisik.

2. Faktor Fungsionalitas

Merupakan faktor yang berhubungan dengan aspek teknis situs web atau aplikasi, yaitu kemudahan pencarian dan navigasi serta desain yang visual dan interaktif (Tandon et al., 2015; Gerht et al., 2012). Terdapat lima sub-dimensi yang termasuk dalam faktor fungsionalitas, yaitu:

\section{a. Usability}

Atribut ini memungkinkan konsumen untuk merasa nyaman ketika menggunakan situs web dalam melakukan pembelian online.

b. Communication

Atribut ini mencerminkan persepsi konsumen mengenai bagaimana perusahaan membangun komunikasi yang dapat mengurangi resiko dalam $e$ commerce, seperti pesan konfirmasi pembelian atau pesan yang menindaklanjuti suatu komplain.

c. Product Presence

Product presence berkaitan dengan penilaian produk/layanan berdasarkan aspek virtual aplikasi sehingga konsumen dapat mengenal produk/layanan dan meningkatkan niat beli.

\section{d. Social Presence}

Adanya interaksi virtual konsumen dengan pembeli lain maupun perusahaan melalui komentar, ulasan produk, dan hubungan media sosial. Namun subdimensi social presence tidak akan diuji pada penelitian ini karena dalam aplikasi GO-FOOD tidak terdapat sub-dimensi social presence.

e. Interactivity

Interactivity menggambarkan pengaruh dinamis komunikasi antar situs web/aplikasi dengan konsumen secara kustomisasi dan personalisasi.

Dalam penelitiannya, Klaus (2013) tidak hanya menemukan bukti pentingnya subdimensi customer service experience, tetapi juga menambahkan aspek dinamis untuk membangun online customer service 
Viany Revita Wijaya, Grace Irene Warouw, Sienny Thio: PERBEDAAN COSTUMER

SERVICE EXPERIENCE PADA GENERASI Y DAN GENERASI Z DALAM

MELAKUKAN PEMESANAN ONLINE FOOD DELIVERY

MELALUI APLIKASI GO-FOOD

experience dengan menghubungkan sub dimensi ke tahapan perjalanan pembelian konsumen yang dapat dilihat pada gambar berikut:

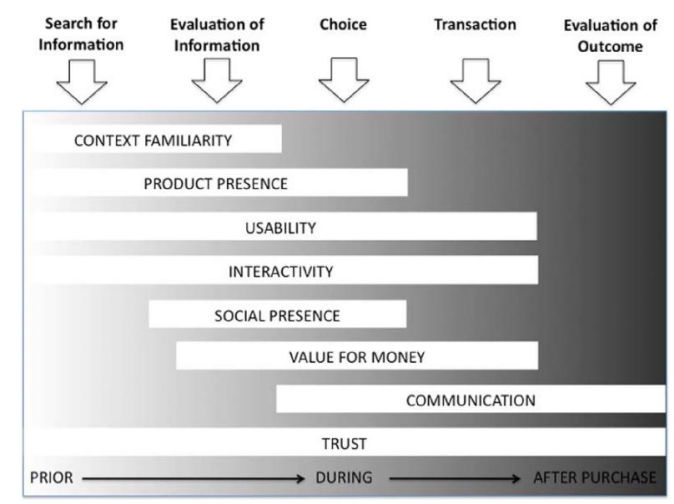

Gambar 1. Model Dinamis Online Customer Service Experience Sumber: Klaus (2013)

Secara khusus, dalam penelitian ini mengungkapkan sub-dimensi mana yang lebih relevan selama urutan tahapan perjalanan pembelian pelanggan. Urutan perjalanan pelanggan dimulai dari mencari informasi, mengevaluasi informasi, memilih, melakukan transaksi, dan mengevaluasi hasil. Tahap perjalanan pelanggan dalam OCSE juga dapat disejajarkan dan disesuaikan sebagai tiga tahap sebelum, selama, dan setelah pembelian. Sub-dimensi customer service experience dapat dilihat dan dipahami secara lebih rinci sesuai dengan proses pembelian-sebelum, selama, atau setelah terjadi transaksi pembelian.

\section{Generasi Y}

Generasi Y dikenal pula sebagai generasi Millenial yang lahir antara tahun 1980 dan 2000 (Miller and Associates, 2011) merupakan generasi terbesar sepanjang sejarah (Solomon, 2014), yang merasa nyaman dengan teknologi dan lebih menyukai berkomunikasi melalui internet daripada berbicara bertatapan muka.

Menurut Debard (2004) generasi Y memiliki beberapa karakteristik:

a. Meninggi terhadap otoritas

b. Memiliki tujuan untuk membangun karir secara paralel c. Memiliki kehidupan yang terlindungi sebagai anak-anak

d. Suka bertanya mengenai cara untuk membuat sesuatu

\section{Generasi $\mathbf{Z}$}

Generasi Z merujuk pada generasi yang lahir pada dekade setelah kemunculan World Wide Web, yaitu antara tahun 2000 hingga sekarang. Generasi $\mathrm{Z}$ merasa nyaman dengan web karena merasa dapat berkomunikasi dengan lebih baik melalui web, juga dikenal sebagai generasi yang diam karena teknologi yang menguasai sebagian besar dari kehidupan rutinitas sehari-hari (Wood, 2013).

Menurut (Wood, 2013) dijelaskan bahwa ada empat karakteristik dari generasi $\mathrm{Z}$ sebagai konsumen, yaitu:

a. Berfokus pada inovasi

b. Kebutuhan akan kenyamanan

c. Keinginan yang mendasar akan adanya keamanan atau rasa aman

d. Adanya kecenderungan untuk mencari hiburan

\section{Sharing Economy}

Sharing economy merupakan model ekonomi yang didukung oleh jaringan teknologi yang memungkinkan pertukaran barang, layanan, atau keterampilan dengan cara dan pada skala yang sebelumnya tidak memungkinkan (Botsman dan Rogers, 2010).

Matzler dan Kathan (2014) mengidentifikasi strategi berbeda yang dapat diterapkan oleh perusahaan agar berhasil dalam bisnis sharing economy, yaitu:

1. Menjual kegunaan, bukan kepemilikan

2. Mendukung kepemilikan kembali atas produk yang sudah pernah digunakan dengan menjual barang/produk dan layanan tersebut

3. Mengambil keuntungan dari sumber daya dan fasilitas yang tidak digunakan

4. Menyediakan fasilitas perbaikan dan layanan pemeliharaan

5. Menargetkan konsumen baru

6. Mengembangkan model bisnis yang benarbenar baru berdasarkan konsep sharing economy.

Online Food Delivery Service 
Online food delivery service merupakan layanan online-to-offline $(\mathrm{O} 2 \mathrm{O})$ yang menyatukan restoran-restoran yang telah bekerja sama dengan pihak OFD service dan menjadi perantara pembelian antara restoran dengan konsumen (Lan; Ya'nan; Shuhua, 2016).

Suhartanto et al. (2018) mengidentifikasi ada dua faktor yang mempengaruhi kesetiaan konsumen secara langsung dalam menggunakan OFD service, yaitu:

1. E-service quality

Menurut Zeithaml et al (2002), e-service quality dapat dilihat dari fitur yang diberikan dalam sebuah aplikasi atau situs web dalam memfasilitasi konsumen dalam memilih produk/jasa.

\section{Food Quality}

Chang et al. (2014) mengungkapkan bahwa kualitas makanan mempengaruhi konsumen dalam membeli makanan secara online.

\section{METODE}

Penelitian ini menggunakan nonprobability sampling dengan metode purposive sampling dimana kuesioner disebarkan kepada 300 Responden yang merupakan masyarakat generasi $\mathrm{Y}$ dan generasi $\mathrm{Z}$ yang berdomisili di Surabaya, termasuk masyarakat yang tidak berdomisili di Surabaya tetapi tinggal di Surabaya untuk sekolah, bekerja, atau kuliah, serta pernah melakukan pemesanan makanan atau minuman melalui aplikasi GO-FOOD minimum dua kali dalam kurun waktu 6 bulan terakhir (Desember 2018-Mei 2019).

Dari 300 kuesioner yang disebarkan, terdapat 27 kuesioner yang tidak bisa digunakan karena tidak sesuai dengan kriteria sampel yang diinginkan. Oleh karena itu, hanya 273 kuesioner yang sesuai dengan kriteria sampel peneliti dan siap diolah yaitu sebanyak 145 responden yang merupakan generasi Y (lahir pada tahun 1980-2000) dan sebanyak 128 responden yang merupakan generasi Z (lahir pada tahun 2001-2019).

Adapun instrumen penelitian diadopsi dari Klaus (2013) yang kemudian penulis melakukan modifikasi sehingga sesuai dengan obyek penelitian yang dibahas. Instrumen penelitian dapat dilihat pada Tabel 1.

Tabel 1. Instrumen Penelitian

\begin{tabular}{|c|c|c|}
\hline Variabel & Sub Variabel & Indikator \\
\hline \multirow[t]{2}{*}{$\begin{array}{l}\text { Faktor } \\
\text { Psikologi }\end{array}$} & Trust & $\begin{array}{l}\text { - Konsumen percaya untuk membagikan informasi } \\
\text { pribadi di aplikasi GO-FOOD } \\
\text { - Konsumen percaya pihak GO-FOOD menggunakan } \\
\text { data pribadi konsumen dengan bijaksana } \\
\text { - Konsumen percaya akan fitur rincian privacy policy } \\
\text { (kebijakan privasi) di aplikasi GO-FOOD } \\
\text { - Konsumen merasa aman dalam melakukan } \\
\text { transaksi pembelian makanan atau minuman } \\
\text { melalui aplikasi GO-FOOD } \\
\text { - Informasi-informasi yang disampaikan dalam } \\
\text { aplikasi GO-FOOD akurat } \\
\text { - Informasi-informasi yang disampaikan dalam } \\
\text { aplikasi GO-FOOD dapat dipercaya }\end{array}$ \\
\hline & $\begin{array}{l}\text { Value for } \\
\text { Money }\end{array}$ & $\begin{array}{l}\text { - Harga yang ditawarkan di aplikasi GO-FOOD } \\
\text { sebanding dengan kualitas makanan yang dibeli } \\
\text { - Harga yang ditawarkan di aplikasi GO-FOOD } \\
\text { sebanding dengan kualitas minuman yang dibeli } \\
\text { - Harga yang ditawarkan di aplikasi GO-FOOD } \\
\text { sebanding dengan porsi makanan yang dibeli } \\
\text { - Harga yang ditawarkan di aplikasi GO-FOOD } \\
\text { sebanding dengan porsi minuman yang dibeli } \\
\text { - Ongkos kirim yang dibayarkan sebanding dengan harga }\end{array}$ \\
\hline
\end{tabular}


Viany Revita Wijaya, Grace Irene Warouw, Sienny Thio: PERBEDAAN COSTUMER

SERVICE EXPERIENCE PADA GENERASI Y DAN GENERASI Z DALAM

MELAKUKAN PEMESANAN ONLINE FOOD DELIVERY

MELALUI APLIKASI GO-FOOD

\begin{tabular}{|c|c|c|}
\hline Variabel & Sub Variabel & Indikator \\
\hline \multirow{6}{*}{$\begin{array}{l}\text { Faktor } \\
\text { Fungsional }\end{array}$} & & $\begin{array}{l}\text { makanan atau minuman yang dibeli } \\
\text { - Tarif ongkos kirim dalam aplikasi GO-FOOD } \\
\text { terjangkau } \\
\text { - Promo yang ditawarkan GO-FOOD sebanding dengan } \\
\text { harga yang dibayarkan }\end{array}$ \\
\hline & $\begin{array}{l}\text { Context } \\
\text { Familiarity }\end{array}$ & $\begin{array}{l}\text { - Fitur map untuk melihat lokasi pengemudi berguna } \\
\text { bagi konsumen untuk melacak keberadaan pengemudi } \\
\text { - Fitur GO-PAY memudahkan konsumen dalam } \\
\text { melakukan pembayaran } \\
\text { - Fitur choose from cuisines (memilih berdasarkan jenis } \\
\text { masakan) membantu konsumen untuk memilih } \\
\text { makanan atau minuman yang diinginkan } \\
\text { - Fitur my orders (pesanan saya) memudahkan konsumen } \\
\text { untuk melihat kembali makanan atau minuman yang } \\
\text { sudah pernah dipesan sebelumnnya } \\
\text { - Fitur my orders (pesanan saya) memudahkan konsumen } \\
\text { untuk memesan kembali makanan atau minuman yang } \\
\text { sudah pernah dipesan sebelumnya } \\
\text { - Fitur promos everywhere (promo) memudahkan } \\
\text { konsumen untuk memilih makanan atau minuman yang } \\
\text { sedang promo }\end{array}$ \\
\hline & Usability & $\begin{array}{l}\text { - Fitur di dalam aplikasi GO-FOOD mudah diaplikasikan } \\
\text { oleh konsumen } \\
\text { - Konsumen dapat melakukan transaksi pembelian di } \\
\text { aplikasi GO-FOOD dengan mudah } \\
\text { - Konsumen dapat mengakses aplikasi GO-FOOD } \\
\text { dengan mudah dan cepat }\end{array}$ \\
\hline & Communication & $\begin{array}{l}\text { - Fitur chat (obrolan) di aplikasi GO-FOOD } \\
\text { memudahkan konsumen untuk berkomunikasi dengan } \\
\text { pengemudi mengenai pesanan }\end{array}$ \\
\hline & & $\begin{array}{l}\text { - Pesan konfirmasi otomatis dalam proses pembelian } \\
\text { memberikan kepastian bagi konsumen mengenai } \\
\text { pesanan } \\
\text { - Fitur notes to driver (pesan untuk pengemudi) berguna } \\
\text { bagi konsumen menambahkan spesifikasi makanan dan } \\
\text { minuman yang dipesan }\end{array}$ \\
\hline & $\begin{array}{l}\text { Product } \\
\text { Presence }\end{array}$ & $\begin{array}{l}\text { - Fitur explore from categories (kategori) dalam aplikasi } \\
\text { GO-FOOD beragam } \\
\text { - Fitur explore from categories (kategori) dalam aplikasi } \\
\text { GO-FOOD memudahkan konsumen memilih makanan } \\
\text { dan minuman yang diinginkan } \\
\text { - Tampilan gambar makanan dan minuman di aplikasi } \\
\text { GO-FOOD menarik } \\
\text { - Tampilan harga makanan dan minuman di aplikasi GO- } \\
\text { FOOD jelas } \\
\text { - Penjelasan mengenai makanan dan minuman di aplikasi } \\
\text { GO-FOOD rinci } \\
\text { - Penjelasan mengenai makanan dan minuman di aplikasi } \\
\text { GO-FOOD menarik }\end{array}$ \\
\hline
\end{tabular}




\begin{tabular}{|c|c|c|}
\hline Variabel & Sub Variabel & Indikator \\
\hline & Interactivity & $\begin{array}{l}\text { - Fitur recommended restos (rekomendasi restoran) } \\
\text { dalam aplikasi GO-FOOD memudahkan konsumen } \\
\text { memilih makanan dan minuman yang diinginkan } \\
\text { - Fitur foodprints (rekomendasi makanan yang paling } \\
\text { sering dipesan) dalam aplikasi GO-FOOD memudahkan } \\
\text { konsumen memilih makanan dan minuman yang } \\
\text { diinginkan } \\
\text { - Riwayat alamat pengiriman di aplikasi GO-FOOD } \\
\text { menghemat waktu konsumen dalam melakukan } \\
\text { pemesanan makanan dan minuman } \\
\text { - Informasi pribadi yang sudah tersimpan di aplikasi GO- } \\
\text { FOOD menghemat waktu konsumen dalam melakukan } \\
\text { pemesanan makanan dan minuman }\end{array}$ \\
\hline
\end{tabular}

Sumber : diadopsi penulis dari Klaus (2013)

\section{HASIL DAN PEMBAHASAN}

Profil responden dalam penelitian ini dapat dilihat pada table 3 dibawah ini.

\section{Tabel 3. Profil Responden}

\begin{tabular}{|c|c|c|}
\hline Variabel & $\mathbf{N}$ & $\%$ \\
\hline \multicolumn{3}{|l|}{ Jenis Kelamin } \\
\hline Laki-laki & 102 & 37.4 \\
\hline Perempuan & 171 & 62.6 \\
\hline \multicolumn{3}{|l|}{ Usia } \\
\hline 19-39 tahun (Generasi Y) & 145 & 53.1 \\
\hline$\leq 18$ tahun $($ Generasi $Z)$ & 128 & 46.9 \\
\hline \multicolumn{3}{|l|}{ Pekerjaan } \\
\hline Pelajar/Mahasiswa & 246 & 90.1 \\
\hline Profesional (dokter, & 6 & 2.2 \\
\hline dosen, dll) & 18 & 6.6 \\
\hline Pegawai Swasta & 3 & 1.1 \\
\hline \multicolumn{3}{|l|}{ Wiraswasta/Entrepeneur } \\
\hline \multicolumn{3}{|l|}{ Pendidikan Saat ini } \\
\hline $\mathrm{SD} / \mathrm{SMP}$ & 38 & 13.9 \\
\hline SMA/SMK/sederajat & 97 & 35.5 \\
\hline Diploma/sederajat & 3 & 1.1 \\
\hline $\mathrm{S} 1 /$ sederajat & 133 & 48.7 \\
\hline $\mathrm{S} 2 / \mathrm{S} 3$ & 2 & 0.7 \\
\hline \multicolumn{3}{|l|}{ Uang Saku/Penghasilan per bulan } \\
\hline$<$ Rp. 500,000 & 45 & 16.5 \\
\hline Rp. 500,000 - Rp. $1,499,999$ & 88 & 32.2 \\
\hline Rp. $1,500,000$ - Rp. $2,999,999$ & 71 & 26.0 \\
\hline Rp. 3,000,000 - Rp. 5,000,000 & 46 & 16.8 \\
\hline$>$ Rp. $5,000,000$ & 23 & 8.4 \\
\hline \multicolumn{3}{|l|}{$\begin{array}{l}\text { Produk yang sering dipesan di } \\
\text { aplikasi GO-FOOD }\end{array}$} \\
\hline Makanan Berat & 188 & 68.9 \\
\hline Makanan Ringan/Jajanan & 54 & 19.8 \\
\hline Makanan Penutup/Dessert & 6 & 2.2 \\
\hline Minuman & 25 & 9.2 \\
\hline
\end{tabular}

\begin{tabular}{|c|c|c|}
\hline \multicolumn{3}{|l|}{$\begin{array}{l}\text { Biaya dalam sekali transaksi di } \\
\text { aplikasi GO-FOOD }\end{array}$} \\
\hline Rp. 10,000 - Rp. 29,999 & 74 & 27.1 \\
\hline Rp. 30,000 - Rp. 49,999 & 111 & 40.7 \\
\hline Rp. 50,000 - Rp. 79,999 & 65 & 23.8 \\
\hline Rp. 80,000 - Rp. 149,999 & 21 & 7.7 \\
\hline$\geq$ Rp. 150,000 & 2 & 0.7 \\
\hline \multicolumn{3}{|l|}{$\begin{array}{l}\text { Berapa ongkos kirim yang } \\
\text { bersedia dibayarkan }\end{array}$} \\
\hline Rp. 0 atau bebas ongkos kirim & 16 & 5.9 \\
\hline$<$ Rp. 5,000 & 81 & 29.7 \\
\hline Rp. 5,000 - Rp. 14,999 & 145 & 53.1 \\
\hline Rp. 15,000 - Rp. 29,999 & 29 & 10.6 \\
\hline Rp. 30,000 - Rp. 49,999 & 0 & 0 \\
\hline$\geq$ Rp. 50,000 & 2 & 0.7 \\
\hline \multicolumn{3}{|l|}{ Metode pembayaran yang dipilih } \\
\hline Tunai/Cash & 76 & 27.8 \\
\hline Dompet Virtual GO-PAY & 197 & 72.2 \\
\hline
\end{tabular}

Hasil profil responden yang didapat menunjukkan responden dengan jenis kelamin perempuan lebih banyak dibandingkan responden dengan jenis kelamin laki-laki. Karakteristik usia berkaitan dengan dua generasi yang merupakan salah satu kriteria sampel penelitian, responden generasi $\mathrm{Y}$ yang berusia 19-39 tahun lebih mendominasi. Lebih dari setengah populasi responden dalam penelitian ini adalah pelajar dan mahasiswa S1 yang penghasilan per bulan atau uang sakunya rata-rata Rp. 500,000 hingga dibawah Rp. 1,500,000. Dalam melakukan pemesanan di aplikasi GOFOOD, makanan berat adalah produk yang kerap dipesan oleh konsumen dengan rentang harga Rp. 30,000 hingga dibawah 
Viany Revita Wijaya, Grace Irene Warouw, Sienny Thio: PERBEDAAN COSTUMER

SERVICE EXPERIENCE PADA GENERASI Y DAN GENERASI Z DALAM

MELAKUKAN PEMESANAN ONLINE FOOD DELIVERY

MELALUI APLIKASI GO-FOOD

Rp. 50,000. Ongkos kirim yang rela dibayarkan mulai dari Rp. 5,000 hingga dari 50\% konsumen lebih memilih metode pembayaran melalui GO-PAY.

dibawah Rp. 15,000. Sementara itu, lebih

Tabel 4. Analisa Deskriptif

\begin{tabular}{lcccc}
\hline \multirow{2}{*}{ Sub-Dimensi } & \multicolumn{2}{c}{ Generasi Y } & \multicolumn{2}{c}{ Generasi Z } \\
\cline { 2 - 5 } & Mean & $\begin{array}{c}\text { Standar } \\
\text { Deviasi }\end{array}$ & Mean & $\begin{array}{c}\text { Standar } \\
\text { Deviasi }\end{array}$ \\
\hline Trust for & 5.61 & 1.110 & 5.85 & 0.701 \\
\hline $\begin{array}{l}\text { Value } \\
\text { money }\end{array}$ & 0.809 & 5.77 & 0.750 \\
\hline $\begin{array}{l}\text { Context } \\
\text { familiarity }\end{array}$ & 6.19 & 0.661 & 6.04 & 0.659 \\
\hline $\begin{array}{l}\text { Usability } \\
\text { Communication }\end{array}$ & 6.29 & 0.731 & 6.16 & 0.736 \\
\hline $\begin{array}{l}\text { Product } \\
\text { Presence }\end{array}$ & 5.73 & 0.749 & 6.18 & 0.680 \\
\hline \begin{tabular}{l} 
Interactivity \\
\hline
\end{tabular} & 6.02 & 0.781 & 5.77 & 0.695 \\
\hline
\end{tabular}

Berdasarkan tabel 4, dapat dilihat Bagi generasi $\mathrm{Y}$, sub-dimensi yang memberikan pengalaman sangat baik adalah usability kemudian context familiarity, communication, interactivity, product presence, trust, dan yang kurang baik adalah sub-dimensi value for money. Sedangkan bagi generasi Z, sub-dimensi yang memberikan pengalaman sangat baik adalah communication kemudian usability, context familiarity, interactivity, trust, value for money, dan yang kurang baik yaitu subdimensi product presence.

Tabel 5. Uji Normalitas

\begin{tabular}{c|c|c}
\hline & $\boldsymbol{p}$-value & $\boldsymbol{\alpha}$ \\
Kolmogorov-Smirnov Z & 1.157 & 0.05 \\
& & \\
Asymp Sig. (2-tailed) & 0.138 & 0.05 \\
\hline
\end{tabular}

Hasil uji normalitas tabel diatas menunjukkan bahwa nilai KolmogorovSmirnov $Z$ dan Asymp Sig. (2-tailed) lebih besar dari nilai signifikansi 0.05 yang mengandung arti data tersebut berdistribusi normal. Oleh karena itu, data ini telah memenuhi syarat untuk diolah lebih lanjut dalam independent sample t-test.

Tabel 6. Independent sample T-test

\begin{tabular}{c|c|c|c|c}
\hline $\begin{array}{c}\text { Sub- } \\
\text { Dimensi }\end{array}$ & \multicolumn{2}{|c|}{ Mean } & t-values & P \\
\cline { 2 - 5 } Trust & 33.63 & 35.09 & -2.712 & $0.007^{*}$ \\
\hline $\begin{array}{c}\text { Value for } \\
\text { Money }\end{array}$ & 37.70 & 40.36 & -4.002 & $0.000^{*}$ \\
\hline $\begin{array}{c}\text { Context } \\
\text { Familiarity }\end{array}$ & 37.16 & 36.21 & 1.973 & 0.050 \\
\hline Usability & 18.89 & 18.48 & 1.470 & 0.143 \\
\hline $\begin{array}{c}\text { Communi } \\
\text { cation }\end{array}$ & 18.56 & 18.55 & 0.045 & 0.964 \\
\hline $\begin{array}{c}\text { Product } \\
\text { Presence }\end{array}$ & 34.37 & 34.61 & -0.433 & 0.665 \\
\hline Interactivity & 24.09 & 23.93 & 0.482 & 0.630 \\
\hline \multicolumn{5}{|c|}{$*$ level signifikansi <0.05 }
\end{tabular}

Dari tabel diatas dapat diketahui bahwa dari ketujuh sub-dimensi customer service experience terdapat dua sub-dimensi dengan hasil p-value lebih kecil dari nilai signifikansi 0.05 yaitu sub-dimensi trust dan value for money. Dari hasil tersebut, 
dinyatakan hipotesis dalam penelitian ini diterima atau dengan kata lain terdapat perbedaan customer service experience yang signifikan terutama pada sub-dimensi trust dan value for money antara generasi $\mathrm{Y}$ dan generasi Z. Perbedaan tersebut juga dapat dilihat dari hasil mean sub-dimensi trust dan value for money yang dihasilkan oleh generasi $\mathrm{Z}$ lebih tinggi dari generasi $\mathrm{Y}$.

\section{KESIMPULAN}

Hasil penelitian menunjukkan bahwa ketujuh sub-dimensi customer service experience, yaitu trust, value for money, context familiarity, usability, communication, product presence, dan interactvity memberikan pengalaman pada konsumen generasi $\mathrm{Y}$ dan generasi $\mathrm{Z}$ dalam melakukan pemesanan makanan ataupun minuman melalui aplikasi GO-FOOD di Surabaya.

generasi $\mathrm{Y}$ mendapatkan pengalaman yang sangat baik ketika melakukan pemesanan online food delivery dalam subdimensi usability. GO-FOOD mampu memberikan kemudahan serta kecepatan dalam pemesanan maupun pembayaran baik dengan metode tunai/cash atau dompet virtual GO-PAY, selain itu informasiinformasi di aplikasi GO-FOOD seperti informasi promo dan voucher juga dapat mudah dipahami oleh generasi Y. Di sisi lain, generasi $\mathrm{Y}$ mendapat pengalaman kurang baik saat menggunakan aplikasi GOFOOD dalam sub-dimensi value for money karena menurut generasi ini, produk dan layanan yang diberikan oleh GO-FOOD tidak sebanding dengan yang dibayarkan.

Generasi $\mathrm{Z}$ mendapatkan pengalaman yang sangat baik dalam sub-dimensi communication. Hal ini membuktikan bahwa sarana komunikasi yang diberikan oleh GOFOOD dalam bentuk pesan konfirmasi otomatis memberikan kepastian mengenai pesanan serta adanya fitur obrolan pada aplikasi memudahkan konsumen generasi $\mathrm{Z}$ untuk berkomunikasi dengan pengemudi. Sedangkan, sub-dimensi product presence merupakan sub-dimensi yang memberikan pengalaman kurang baik. GO-FOOD belum memberikan penjelasan yang rinci mengenai produk dalam aplikasi sehingga konsumen generasi $\mathrm{Z}$ tidak memiliki gambaran yang cukup mengenai produk apa yang akan dipesan.

Secara karakteristik generasi $Y$ dan generasi $\mathrm{Z}$ berbeda, begitu juga dengan customer service experience kedua generasi ini dalam melakukan pemesanan online food delivery melalui aplikasi GO-FOOD. Dari ketujuh sub-dimensi customer service experience yang telah diuji, didapati hasil bahwa terdapat dua sub-dimensi yang menunjukkan perbedaan yang signifikan, yaitu sub-dimensi trust dan value for money. Tingkat kepercayaan generasi $\mathrm{Z}$ dalam melakukan pemesanan melalui aplikasi GOFOOD lebih tinggi dibandingkan dengan tingkat kepercayaan generasi Y. Selain itu, persepsi generasi $\mathrm{Z}$ mengenai layanan dan produk yang diberikan oleh pihak GO-FOOD sebanding dengan apa yang dibayarkan juga lebih tinggi dibandingkan dengan generasi.

Dari hasil penelitian ini, diharapkan pihak GO-FOOD dapat memahami pengalaman yang dirasakan oleh pengguna aplikasi GOFOOD terutama konsumen generasi $\mathrm{Y}$ dan generasi $\mathrm{Z}$ sehingga dapat memperbaiki, meningkatkan, serta mengembangkan layanan yang diberikan. Sedangkan untuk penelitian selanjutnya, diharapkan dapat menguji dan mengembangkan penelitian ini dengan berbagai metode dan dimensi lain yang berkaitan dengan customer service experience di kota-kota besar di Indonesia seperti Jakarta, Bandung dan Medan. Selain itu, penelitian selanjutnya dapat pula menguji perbandingan customer service experience antar aplikasi online food delivery lainnya seperti Grab Food.

\section{DAFTAR PUSTAKA}

Ajrina, H. N., \& Panji, A. (2016, Maret 29). cnnindonesia. Retrieved from https://www.cnnindonesia.com/teknolo gi/20160329115230-185-

120213/kebangkitan-sharing-economydi-indonesia 
Viany Revita Wijaya, Grace Irene Warouw, Sienny Thio: PERBEDAAN COSTUMER

SERVICE EXPERIENCE PADA GENERASI Y DAN GENERASI Z DALAM

MELAKUKAN PEMESANAN ONLINE FOOD DELIVERY

\section{MELALUI APLIKASI GO-FOOD}

Botsman, R., \& Rogers, R. (2011). What's mine is yours: The rise of collaborative consumption. New York, NY: Harper Business.

Chandra, A. A. (2016, November 21). detikfinance. Retrieved from https://finance.detik.com/beritaekonomi-bisnis/d-3350298/ini-3sektor-ekonomi-kreatif-yang-sumbangpdb-terbesar-ke-

ri?_ga=2.169880992.1226296443.1552 932656-273008563.1551757076

Chang, H. H., \& Chen, S. W. (2009). Consumer perception of interface quality, security, and loyalty in electronic commerce. Information \& Management, 46(7), 411-417. Retrieved from https://doi:10.1016/j.im.2009.08.00

Cho, N., \& Park, S. (2001). Development of electronic commerce user-consumer satisfaction index (ECUSI) for Internet shopping. Industrial Management and Data Systems, 101(8), 400-406. Retrieved from https://doi.org/10.1108/EUM00000000 06170.

Debard, R. (2004). Millennials coming to college. New Directions for Student Services, 2004(106), 33-45. Retrieved from https://doi:10.1002/ss.123

Gitasari, I. (2017, Desember 8). Kompasiana.com. Retrieved from https://www.kompasiana.com/planolog ita/5a298194aeb7d9f24fab2/dampaktingginya-kepadatan-penduduk-disurabaya.

Hutabarat, D. (2018, Januari 19). kominfo. Retrieved from kominfo.co.id: https://www.kominfo.go.id/content/det ail/12412/sharing-economy-tumbuh-ditengah-ketidakefisienan/0/berita_satker

Josina. (2017, September 12). detikinet. Retrieved from inet.detik.com: https://inet.detik.com/cyberlife/d3640129/ini-kebiasaan-pelanggan-gojek-saat-order-go-food

Klaus, P. (2013). The case of Amazon.com: Towards a conceptual framework of online customer service experience (OCSE) using the emerging consensus technique (ECT). Journal of Services Marketing, 27(6), 443-457.

Lan, H., Li, Y., and Wang, S. (2016). Improvement of Online Food Delivery Service Based on Consumers' Negative Comments. Canadian Social Science, 12(5), 84-88. Retrieved from http://dx.doi.org/10.3968/\%25x.

Lemon, K. N., \& Verhoef, P. C. (2016). Understanding Customer Experience Throughout the Customer Journey. Journal of Marketing, 80(6), 69-96. Retrieved from https://doi:10.1509/jm.15.0420

Matzler, K., Veider, V., \& Kathan, W. (2014). Adapting to the Sharing Economy. MIT Sloan Management Review 56(2), 71-77. Retrieved from https://doi.org/10.1007/s11002-0159366-X.

Meyer, C., Schwager, A. (2007). Understanding Customer Experience. Harvard Business Review, 85(2), 116124.

Miller, R. K., Washington, K. Consumer Behavior 2011: Millennial Consumers. Loganville, USA: Richard K. Miller and Associates.

Trevinal, A. M., \& Stenger, T. (2014). Toward a conceptualization of the online shopping experience. Journal of Retailing and Consumer Services, 21(3), 314-326. Retrieved from https://doi:10.1016/j.jretconser.2014.02 .009 .

Wardani, A. S. (2018, Januari 10). liputan6. Retrieved from liputan6.com: https:/www.liputan6.com/tekno/read/3 221001/bos-go-jek-go-food-jadilayanan-antar-makanan-terbesar-didunia

Wood, S. (2013). Generation Z as consumers: trends and innovation. Institute for Emerging Issues: NC State University, 1-3. Retrieved from https://iei.ncsu.edu/wp- 
Journal of Indonesian Tourism, Hospitality and Recreation --- Volume 2, No. 2, October 2019 eISSN: 2654-4687 ----- pISSN: 2654-3893

content/uploads/2013/01/GenZConsum ers.pdf.

Zeithaml, V. A., Parasuraman, A., \& Malhotra, A. (2002). Service quality delivery through web sites: A critical review of extant knowledge. Journal of the Academy of Marketing Science, $30(4), 362-375$. 